\title{
The Employment Effect Of Outward FDI On Home Country
}

\author{
Zheng Yueming \\ Wuhan University of Science and Technology Hubei, China
}

Keywords: Three industries; Outward FDI; Employment

\begin{abstract}
With the implementation of "Going abroad" strategy, an increasing number of enterprises have carried out the activities of outward investment, and the effect of outward FDI on the home country labor market has aroused widespread concerns. This article will analyze this issue from the perspective of different industries. Specifically, this article will set up cross sections by making use of Chinese three industries, and set up dynamic panel data model by using data sample of each cross section from 2004-2012 to analyze the influence of outward FDI on employment of different industries. According to the results, significant differences exist among the impacts of outward FDI on domestic employment of industries. Outward FDI has a negative effect on the job creation in Primary industry and Secondary industry, although it is not significant, while it has a significant effect on the Tertiary industry in terms of job creation.
\end{abstract}

\section{Introduction}

China, the biggest developing country and the most populous country, constantly gives priority to the domestic employment issue because it is the key factor to maintain the social harmony. Currently, the unemployment issue is becoming increasingly serious with the deepening of the economic reforms and the acceleration of the adjustment of industrial structure. Meanwhile, outward FDI is increasing rapidly with the carrying out of the "Go abroad" strategy in the $21^{\text {st }}$ century, and the impact of outward FDI on domestic labor market cannot be ignored any more, especially the influence of the Secondary industry on domestic employment market is becoming increasingly stronger. Previous researches indicate that outward FDI will result in promoting and replacing effect on the employment of the home country, and the influence will be different in different regions and time periods. Some scholars have done researches on the effect of different outward FDI on the domestic labor market from other perspectives, this article is going to carry out the research from another angle, that is the effect of different outward FDI from different industries on the domestic labor market. The article is organized as followed: chapter 1 is the introduction of this paper, and chapter 2 is the literature review to summarize the established researches, chapter 3 is the empirical analysis, and final chapter is the conclusion and the corresponding suggestions.

\section{Literature Review}

There are numerous researches focusing on the employment effect of outward FDI, and all of them have the consensus that outward FDI may have the promoting effect and replacing effect on the employment, and most of them reach the conclusion from the perspective of different investment subjects and investment destinations. However, it is quite rare to find articles analyzing this based on the different industries of source country. To sum up, there are basically three kinds of opinions:

Firstly, outward FDI will promote the employment in home country, because outward FDI may increase new production capacity at home and this will directly lead to the creation of new jobs. At the same time, the increase of new production capacity may promote the development of the upstream and downstream industries, and this will indirectly create jobs at home. ( Hawkins , 1972 ; Lipsey , 1994 ; Blomstrom , 1997 ; Lipsey\&Weiss , 1981 ; Blomstrom , 1988 ; Hufboauer , 1994 ; Pfaffermayer , 1994 ; Swedenborg , 1985 ; Fontagne\&Pajot , 1997 ; Yang Jianqing , 2004 ; Luo Liangwen , 2004) . 
Secondly, outward FDI will prohibit the employment in home country, because outward FDI may partly or even completely transfer the resources to the host countries and this may decrease the investment opportunities in the home countries. If the capital resources are limited in a country and outward FDI doesn't lead to the increase of export or the decrease of import, then outward FDI will substitute partial domestic investment and consumption, and finally result in replacing effect on the domestic employment. ( Stevenson , 1996 ; Brainerd\&Riker , 1997 ; Hatzius , 1997).

Thirdly, the effect of outward FDI on the domestic employment is uncertain and the effect is depending on many factors. Some scholars assist that outward FDI may have promoting and replacing effect on the employment in the home country, and the comprehensive effect is determined by many factors such as the distribution of outward FDI in industries ( Robert E . Lipsey , 2000 ; Campbell , 1994 ; Kravis , 1988 ) .

There are a few researches focusing on the effect of outward FDI from different industries on the domestic employment. The result shows that Chinese outward FDI has the most significant promoting effect on the Tertiary industry, and followed by the manufacturing industry and mining industry.(Liu huiqun 2011)

\section{Empirical analysis}

(1) The status quo of Chinese outward FDI based on industries

Even though all of the outward FDI is from the three industries, there are great difference in terms of amount and proportion. From the perspective of industry sources, the percentage of outward FDI from the Tertiary industry is always dominant even there are some fluctuations, standing at just over 50\%.(see the graph 1 ). And specifically, the proportion reached the highest point at $82 \%$ in 2008. In contrast, the proportion of outward FDI from the Secondary industry constantly stands at between $20 \%---40 \%$, and the proportion from the Primary industry is the least, representing just below $1 \%$.

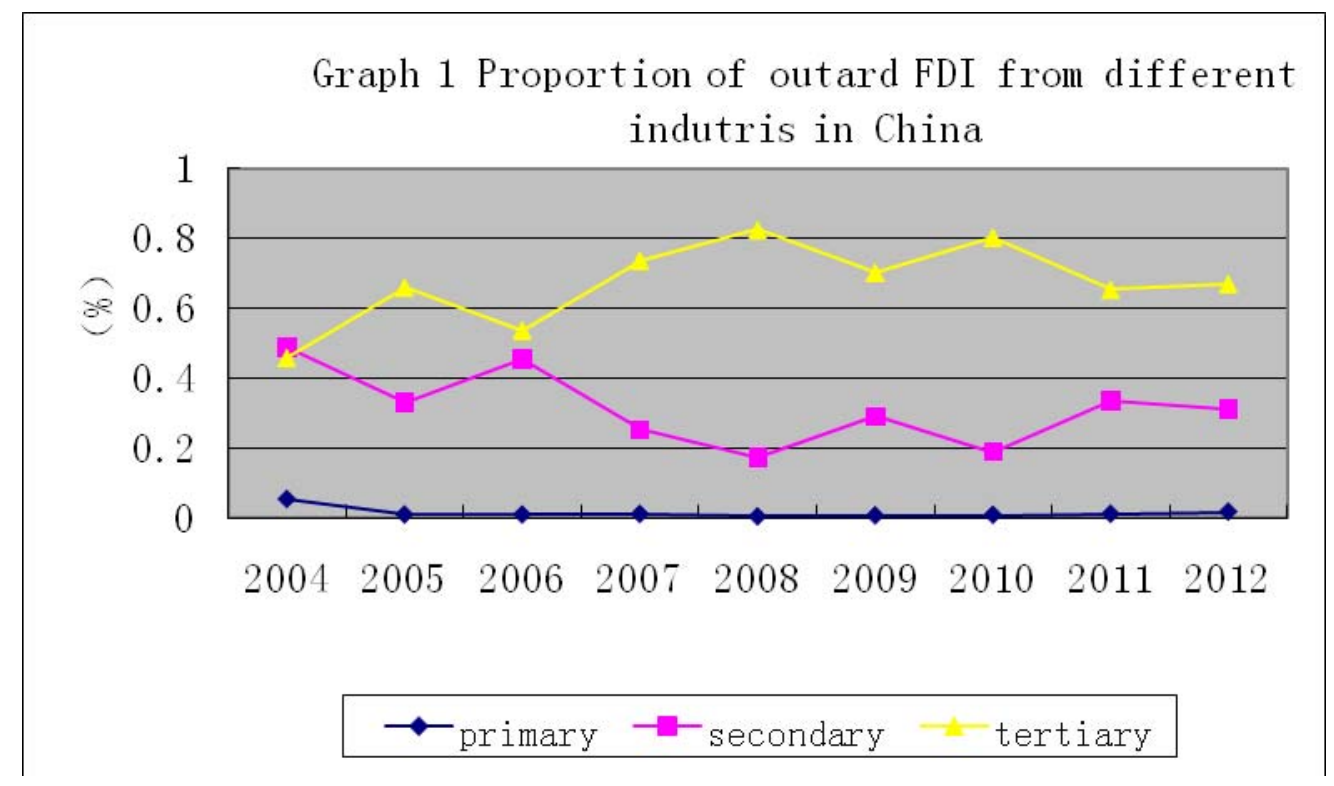

Sources: 2004-2012 《Statical Bulletin of China’s Outward Foreign Direct Investment》

We will use a ratio to reflect the difference of outward FDI of different industries, that is ratio $=X_{\max } / X_{\min }$. In order to compare the difference among industries, we regard the outward FDI of the Primary industry as the benchmark and compare respectively with the outward FDI from 
Secondary and Tertiary industries. According to the results(see graph 2), the distribution gap of outward FDI between the Tertiary industry and the Primary industry was widening gradually before 2008, and the gap narrowed down after 2008; the distribution gap of outward FDI between the Secondary industry and the Primary industry experienced fluctuations from 2004-2012, but basically, it remains relatively stable; the distribution gap of outward FDI between the Tertiary industry and the Secondary industry is quite stable, standing at very low value during the whole time period. Based on the above-mentioned analysis, we can know that the proportion of China's outward FDI is different according to the source of industries, and the relative trend among these industries is also different. Therefore, we have to take into account the distribution differences of outward FDI and the possible influence of this difference on our research when we analyze its effect on the domestic labor market.

Graph 2 the extreme ratio of outward FDI in three industries (\%)

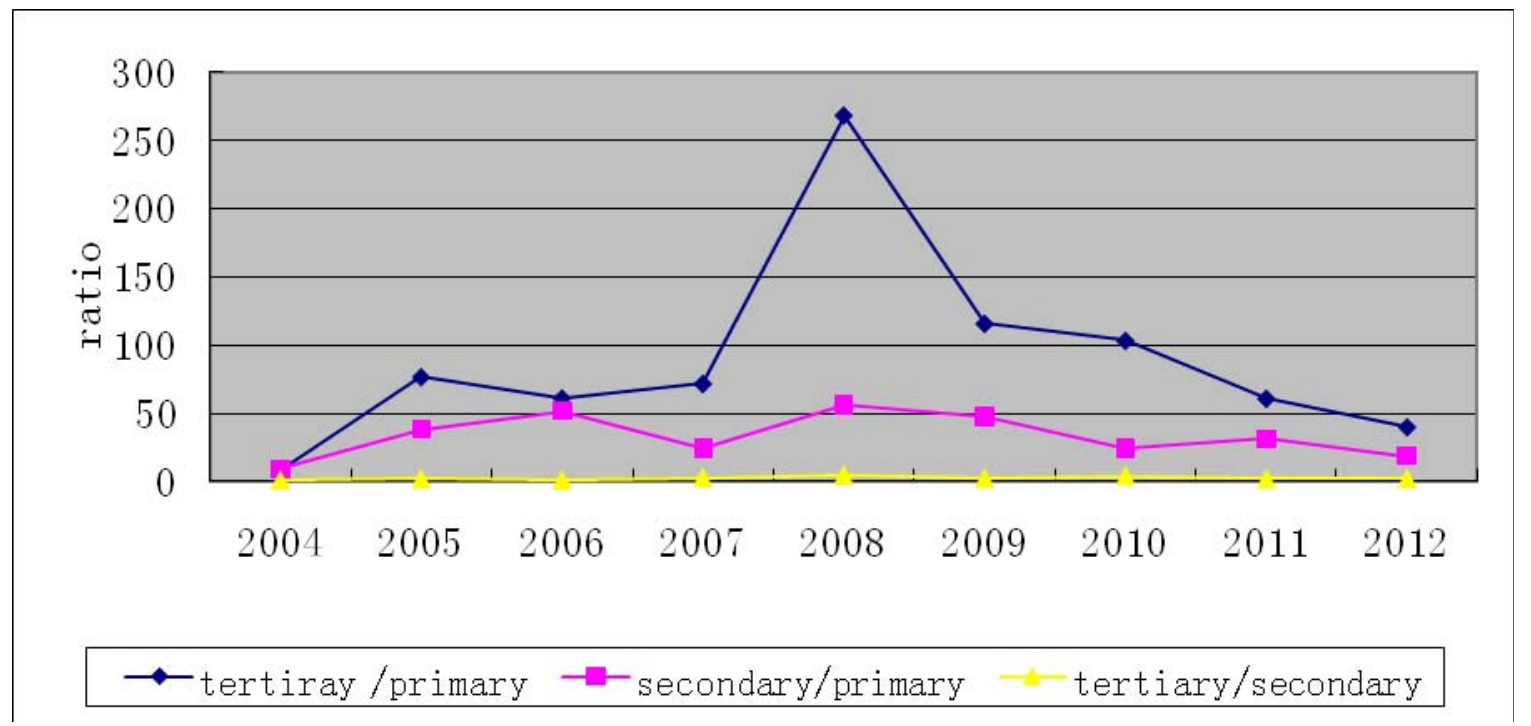

Sources: 2004-2012 《Statical Bulletin of China’s Outward Foreign Direct Investment》

(2) Model and estimation

Since the source of China's outward FDI is different and the capital content of different source is not same, therefore, the impact of different outward FDI from various sources will be different. In order to reflect this difference, we will set up dynamic panel data model to estimate the possible impact.

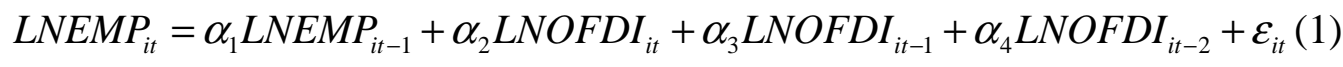

$\mathrm{i}=1 、 2 、 3$, means the primary secondary 、 tertiary industry respectively

$\mathrm{t}=2004 \ldots \ldots . .2012$, means the time period is between 2004-2012. $E M P_{i t}$ is the number of the domestic employment and $O F D I_{i t}$ is the amount of China's outward FDI from domestic three industries, $L N O F D I_{i t-1}$ and $L N O F D I_{i t-2}$ is the lag(1) and lag(2) of LNOFDI. $\alpha_{1}$ indicates the effect of previous employment on the current employment, $\alpha_{2}$ indicates the effect of outward FDI on the domestic employment, $\alpha_{3}$ and $\alpha_{4}$ indicates the effects of OFDI lag(1) and OFDI lag(2) on the domestic employment. Hence, we can tell from these coefficients whether China's outward FDI has positive or negative effect on domestic employment. The effect will be positive if the value of the coefficient is bigger than zero, while the effect will be negative if the value of the coefficient is smaller than zero. 
The biggest challenge of the dynamic panel data model is the methodology of its estimation, because the estimation result will be biased if we still adopt the standard fixed effect or the random effect to estimate the model. In order to maintain the consistency of the estimation result, we are going to use system-GMM to do the estimation with the help of software stata 11.0. The estimation result is listed below:

Table 1 the estimation result of model (1)

\begin{tabular}{|c|c|c|c|c|}
\hline & $\alpha_{1}$ & $\alpha_{2}$ & $\alpha_{3}$ & $\alpha_{4}$ \\
\hline Primary industry & $\begin{array}{c}0.8599 \\
(0.000) \text { * }\end{array}$ & $\begin{array}{l}-0.0138 \\
(0.383)\end{array}$ & $\begin{array}{c}0.0004 \\
(0.981)\end{array}$ & $\begin{array}{l}-0.0029 \\
(0.807)\end{array}$ \\
\hline $\begin{array}{l}\text { Secondary } \\
\text { industry }\end{array}$ & $\begin{array}{c}1.0343 \\
(0.019)\end{array}$ & $\begin{array}{l}-0.0285 \\
(0.482)\end{array}$ & $\begin{array}{l}-0.0090 \\
(0.784)\end{array}$ & $\begin{array}{c}0.0066 \\
(0.823)\end{array}$ \\
\hline Tertiary industry & $\begin{array}{c}1.0531 \\
(0.000)\end{array}$ & $\begin{array}{c}0.0092 \\
(0.615)\end{array}$ & $\begin{array}{c}0.0286 \\
(0.027) * *\end{array}$ & $\begin{array}{l}-0.0259 \\
(0.463)\end{array}$ \\
\hline nation & $\begin{array}{c}1.0834 \\
(0.000)\end{array}$ & $\begin{array}{c}-0.0032 \\
(0.001) *\end{array}$ & $\begin{array}{l}-0.0001 \\
(0.924)\end{array}$ & $\begin{array}{c}0.0006 \\
(0.402)\end{array}$ \\
\hline
\end{tabular}

Notes: (1)the value in the round brackets is the $\mathrm{P}$ value of estimator,

* , ${ }^{*} *$ means the coefficient is significant at level $1 \%$ and $5 \%$ respectively

According to the table 1, China's outward FDI has the prohibiting effect on the domestic job creation in the primary industry, but this effect is not obvious because the test result of coefficient is not significant. As for the secondary industry, outward FDI also has the negative effect on the employment at home country, and the effect is also insignificant as the test result is not significant. In terms of the tertiary industry, the current outward FDI and the lag(1) outward FDI have the positive effect on the domestic employment, which means the outward FDI is helpful for the job creation at home country. Furthermore, the test results of these estimator are significant, which means the promoting effect is significant. However, the lag(2) outward FDI has the replacing effect on the employment and the effect is not significant. From the perspective of the whole nation, the outward FDI generally has the insignificantly negative effect on the domestic employment.

\section{Conclusions and suggestions}

(1) Conclusions

Based on the above analysis, we can understand that the effect of outward FDI on the domestic employment is different according to the different industries. As for the primary and secondary industry, the overall effect on the employment at home country is negative even though it has some positive effect to some extent. In terms of the tertiary industry, the overall effect is positive and the result is significant. There are maybe three reasons contributing to the result:

Firstly, the total value of the outward FDI from the primary industry is not very high, and the capital/technology contents are relatively high, so the investment won't lead to significant replacing effect. However, when the products made by the outward FDI shipped back to domestic market 
through international trade, it will cause a shock to the domestic market and may lead to the decrease of employment. Fortunately, the effect is not significant.

Secondary, outward FDI from the secondary industry is mainly capital/technology intensive, but a certain amount of investment is to take advantage of the cheap local labor forces and raw materials. Therefore, these two factors have to been considered when we are analyzing the outward FDI effect. If the investment is capital/technology intensive, the outward FDI will promote the domestic employment through the increasing export of domestic raw materials and semi-finished products through international trade. If the purpose of outward FDI is to make use of cheap local labor forces and raw materials, it will replace the employment at home, because the investment will decrease the demand of raw materials and semi-finished products from home country. In summary, the overall effect depends on the influence of international trade derived from outward FDI on the domestic market, which is proved by the results of the economic model.

Thirdly, most of the outward FDI from the tertiary industry focuses on the business services, finance and architecture which have significant promoting effect on the domestic employment. With the development of globalization, the tertiary industry plays a big role in the job creation, so the outward investment will increase the demand of workers from home country, such as workers in the architecture industry and wholesale and retailing industry, which will in turn promote the domestic employment. And according to the estimation results of the model, outward FDI from the tertiary industry can significantly promote the job creation at home country

\section{(2) Suggestions}

In order to make full use of the positive effect of outward FDI, some suggestions are given as below:

Firstly, Chinese government should encourage domestic enterprises to go abroad to expand market shares, because only by doing this can we increase the demand for labor forces and raw materials, which will in turn increase the jobs at home country.

Secondary, different investment destinations and investment subjects will lead to different effect on the domestic employment. If the purpose is to take advantage of the cheap labors and raw materials, the outward FDI can't significant enhance employment at home through international trade. In contrast, the investment in developed countries will import a large number of raw materials and semi-finished products, which will have positive effect on the employment at home.

Thirdly, it is beneficial to develop the tertiary industry to promote employment because the promoting effect of the tertiary industry is widely proved and accepted in the whole world. So, companies should be encourage to invest in the tertiary industry to help promote the employment at home.

\section{References}

[1] Tain-Jy Chen and Yin-Hua Ku.. The Effect of Overseas Investment on Domestic Employment. NBER working paper. 2003

[2] Wu F, Heng TM, Ho T. Outward Foreign Direct Investment and its Impact on the Home

Economy : The Case of Singapore [J] Journal of Asian Business 2003,19(3) 25-30

[3] Ellingsen C, Likumanhuwa W, Nunnenkamp P. Outward FDI by Singapore: A Different Animal?

[J] Transnational Corporation 2006,15 (2) 1--40

[4] Mihir A D , Fritz F , James R H . The Internal Markets of Multinational Finns[J] . Survey of

Current Business , 2007 , 87(3) : 42-48 . 
[5] Chen T J , Ku Y H . The Effect of Foreign Direct Investment on Fin Growth : The Case of Twain Manufacture[J] . Japan and the World Economy . 2000 , (2) : 153-172 .

[6] Wu F , Heng T M , Ho T . Outward Foreign Direct Investment and its Impact on the Home Economy : The Case of Singapore[J] . Journal of Asian Business(University of Michigan) , $2003,19(3): 27-48$.

[7] Lipsey R E . Outward FDI and Parent Exports and Employment : Japan , the United States and Sweden[R] . NBER Working Paper , 2000 .

[8]Luo Liangwen . The Employment Effect of Outward FDI : Theory and Empirical Study in China[J] . Journal of Zhongnan University of Economics and Law , 2007 ，(5) : 87—91 .

[9] Chai Linru . Effects of China's FDI on its Own Employment[J] . Journal of Hebei University of Economics and Trade , 2008 , (5) : 55-58

[10] LuoLiying , HuangNa . The Empirical Analysis of China'8 Outward FDI on Employment[J] . Shanghai Economic Review , 2008 , (8) : 86-91 .

[11] Yu Chao , Ge Heping . The Study of Home Country Employment Effect of Outward FDI $[J]$. Statistics and Decision Making , $2011,(20): 123-125$

[12] Huang Xiaoling , Liu Huizheng . Analysis on Employment Effect of China's Outward FDI[J] . Modernization of Management , 2007 , (5) : 45-48 .

[13] Liu Huiqun , Wang Yang . Analysis on Domestic Employment Effect of China’s Outward FDI : Based on Investors and Industries 『J] . Journal of Interactional Business and Economics , $2011,(4): 82-87$.

[14] Mao Risheng . Export , FD1 and Employment in Manufacturing Industries of China[J] . Economic Research Journal , 2009 , (11) : 105 - l17 